\title{
Upper Neches River Basin Caddo Ceramics, an Attempt at an Updated Seriation and a Context for Understnading Frankston to Allen Phase Ceramic Stylistic and Technological Changes
}

Timothy K. Perttula

Heritage Research Center, Stephen F. Austin State University

Follow this and additional works at: https://scholarworks.sfasu.edu/ita

Part of the American Material Culture Commons, Archaeological Anthropology Commons, Environmental Studies Commons, Other American Studies Commons, Other Arts and Humanities Commons, Other History of Art, Architecture, and Archaeology Commons, and the United States History Commons

Tell us how this article helped you.

This Article is brought to you for free and open access by the Center for Regional Heritage Research at SFA ScholarWorks. It has been accepted for inclusion in Index of Texas Archaeology: Open Access Gray Literature from the Lone Star State by an authorized editor of SFA ScholarWorks. For more information, please contact cdsscholarworks@sfasu.edu. 
Upper Neches River Basin Caddo Ceramics, an Attempt at an Updated Seriation and a Context for Understnading Frankston to Allen Phase Ceramic Stylistic and Technological Changes

Creative Commons License

(c) (1) (9)

This work is licensed under a Creative Commons Attribution-NonCommercial 4.0 International License 


\section{UPPER NECHES RIVER BASIN CADDO CERAMICS, AN ATTEMPT AT AN UPDATED SERIATION AND A CONTEXT FOR UNDERSTANDING FRANKSTON TO ALLEN PHASE CERAMIC STYLISTIC AND TECHNOLOGICAL CHANGES}

\section{Timothy K. Perttula}

Table 1 provides comparative sherd assemblage data from Lake Palestine sites on the Neches River (see Anderson et al. 1974), 41HE139 west of Lake Palestine (Cliff et al. 2004), 4 I AN38 (Kclley et al. 2006) south of Lake Palcstine, as well as the Kah-hah-kowha site (41CE354) (Perttula and Nelson 2006) to the northeast of the lake. This site has an Allen phasc component. The Lake Palestine sites include Debro (41CE86), William Sherman (41CE30), Forest Drive (41HE184), Halbert, Woldert (41HE80), Ferguson, Tomato Patch (41HEI85), Mitchell (41HE22), and White Mule (41HE166) (Figure 1).

Table 1. Comparative sherd assemblage data from Lake Palestine Caddo sites, $41 \mathrm{AN38}$, and $41 \mathrm{CE} 354$, and proposed temporal sequence of sites.

\begin{tabular}{|c|c|c|c|c|c|c|}
\hline Site & $\begin{array}{l}\text { No. of Dec. } \\
\text { Sherds }\end{array}$ & \% Brushed* & $\begin{array}{l}\text { \%bone- } \\
\text { temper }\end{array}$ & $\begin{array}{l}\text { \%Wet-paste } \\
\text { decorations }\end{array}$ & $\mathbf{P} / \mathbf{D R}$ & $\begin{array}{l}\text { Brushed/Wet } \\
\text { paste ratio }\end{array}$ \\
\hline \multicolumn{7}{|c|}{ YOUNGEST SITE: GROUP la, known Allen phase component } \\
\hline $41 \mathrm{CE} 354$ & 474 & 82.7 & 3.1 & 8.9 & 0.20 & 8.14 \\
\hline \multicolumn{7}{|c|}{ GROUP Ib, YOUNGEST FRANKSTON PHASE SITES } \\
\hline Debro & 311 & 80.0 & $?$ & 10.3 & 0.14 & 7.75 \\
\hline $\begin{array}{l}\text { William } \\
\text { Sherman }\end{array}$ & 525 & 75.8 & ? & 16.2 & 0.44 & 4.68 \\
\hline \multicolumn{7}{|l|}{ GROUP II } \\
\hline Forest Drive & 1693 & 68.6 & ? & 21.9 & 0.56 & 3.12 \\
\hline Ilalbert & 1757 & 65.8 & 2.6 & 26.3 & 0.70 & 2.51 \\
\hline Woldert & 1730 & 62.7 & 0.0 & 28.8 & 0.72 & 2.19 \\
\hline Ferguson & 4116 & 60.8 & $<1.0$ & 27.9 & 0.61 & 2.17 \\
\hline \multicolumn{7}{|c|}{ GROUP III, OLDEST FRANKSTON PHASE SITES } \\
\hline Tomato Patch & 912 & 49.2 & $?$ & 41.7 & 1.50 & 1.21 \\
\hline $41 \mathrm{AN} 38$ & 2435 & 35.9 & 6.7 & 38.0 & 1.40 & 0.91 \\
\hline Mitchell, De & 54 & 32.1 & 0.0 & 33.3 & 1.37 & 1.50 \\
\hline
\end{tabular}


Table 1. Comparative sherd assemblage data from Lake Palestine Caddo sites, 41AN38, and 41CE354, and proposed temporal sequence of sites, cont.

\begin{tabular}{|c|c|c|c|c|c|}
\hline Site & $\begin{array}{l}\text { No. of Dec. } \\
\text { Sherds }\end{array}$ & \% Brushed* & $\begin{array}{l}\text { \%bone- \%Wet-paste } \\
\text { temper decorations }\end{array}$ & P/DR & $\begin{array}{l}\text { Brushed/Wet } \\
\text { paste ratio }\end{array}$ \\
\hline
\end{tabular}

MIDDLE AND EARLY CADDO GROUPS

$\begin{array}{lllllll}\text { GROUP IV } & & & & & & \\ \text { White Mule } & 1404 & 18.5 & 1.5 & 63.7 & 2.61 & 0.29 \\ \text { 41HE139 } & 40 & 17.5 & 8.1 & 65.0 & 2.51 & 0.33 \\ & & & & & \\ \text { OLDEST SITE: GROUP V } & & 1.3 & 12.0 & 65.7 & 1.71 & 0.03 \\ \begin{array}{lllll}\text { Mitchell, A-C } & 56\end{array} & 1.3 & & & \end{array}$

*percentage of all decorated sherds; other comparisons in this volume use percentage of brushed sherds relative to all sherds, both plain and decorated

These comparisons of the composition of upper Neches River basin Caddo decorated sherd assemblages - and the temporal orderings and cultural affiliations they imply - are based on the percentage of brushed sherds in the decorated sherd sample (rather than the percentage of brushed sherds among all the sherds, both plain and decorated), the percentage of bone temper in the assemblages, the percentage of wetpaste decorations other than brushing (i.e., incised, punctated, appliqued, neck-banded, etc.), the plain/decorated sherd ratio (P/DR), and the brushed sherd/wet paste decorated sherd ratio (see Table 1). From these comparisons, six different groups of assemblages have been defined in a seriation of the Lake Palestine area sites. These groups seem to reflect temporal changes due to the high frequency of Latc Caddo Frankston phase decorated types, such as Poynor Engraved, Maydelle Incised, Bullard Brushed, Hume Engraved, and engraved effigy vessels, that are found in the Groups Ib-III sites - as well as Patton Engraved sherds from 41CE354 in Group la-and the occurrence of Early and Middle Caddo types such as Canton Incised, Dunkin Incised, Holly Fine Engraved, and Pennington Punctated-Incised in the Group IV and V Lake Palestine sites. 


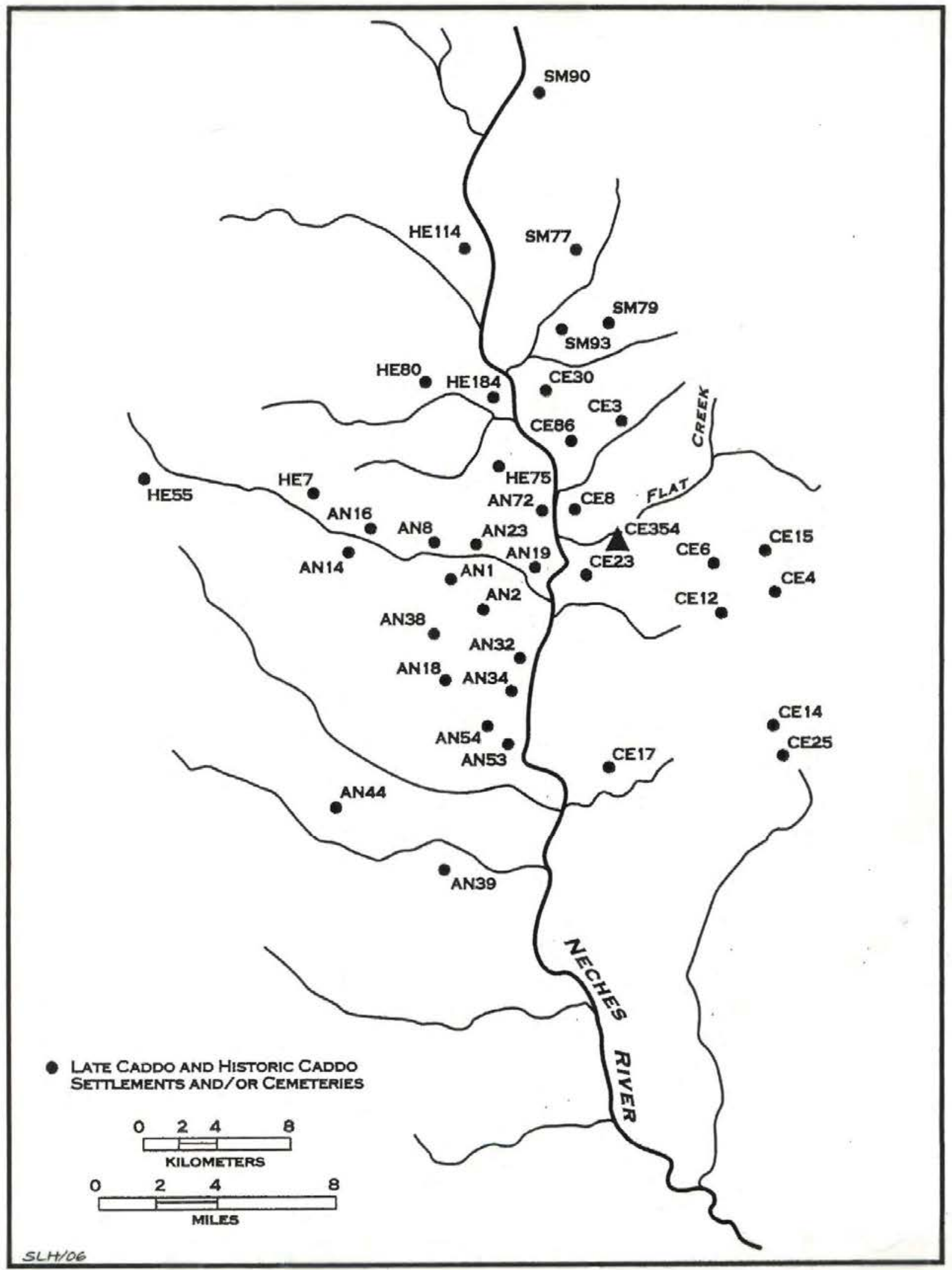

Figure 1. Selected Frankston and Allen phases in the upper Neches River basin, Anderson, Cherokee, Henderson, and Smith counties, Texas. 
This particular seriation, with three different temporal groupings of Frankston and Allen phase sites, is aalso supported by ifferences in: (a) the proportions of Poynor Engraved varieties, Patton Engraved, engraved effigy vessels, Maydelle Incised, La Rue Neck Banded, and Bullard Brushed in upper Neches River Caddo burials, (b) differences in the relative frequencies of common vessel forms in Poynor and Patton Engraved vessels (Kleinschmidt 1982:Figure 24), as well as (c) the occurrence of European trade goods. The Kah-hah-ko-wha site (41CE354) is in Group Ia of the seriation (see Table 1), and is interpreted as the youngest or most recent known Caddo occupation of the Lake Palestine area sites. Corbin (2007, this volume) considers the Group lb-III Caddo sites part of an upper Neches River cluster that represents a conglomeration of constitutent groups that share a broadly similar socio-political organization through time and space (see Story and Creel 1982:30-34).

No Sanders phase pottery types (i.e., Sanders Engraved, Monkstown Fingernail Impressed, Maxey Noded Redware) were recovered in the Lake Palestine sites. Furthermore, it has been shown in several other ceramic studies in northeastern Texas that the proportion of brushed sherds in decorated sherd assemblages steadily increases through time, beginning after ca. A.D. 1250, during the occupation of the Group IV Caddo sites (and after the principal Early Caddo occupation ended at the George C. Davis site, i.c. after ca. A.D. 1250-1300). By the late 17th and 18th centuries Caddo sites are known in the Neches and Angelina river basins (including Deshazo) where brushed sherds account for ca. $50-90 \%$ of all the decorated sherds. More than $82 \%$ of the sherds at the $17^{\text {th }}$ century Kah-hah-ko-wha site (41CE354) are brushed (see Table 1). This site appears to be the youngest Caddo site in the proposed seriation.

\section{References Cited}

Anderson, K. M., K. Gilmore, O. F. McCormick III, and E. P. Morenon

1974 Archaeological Investigations at Lake Palestine, Texas. Contributions in Anthropology No. 11. Southern Methodist University, Dallas.

Cliff, M. B., E. C. Sills, T. K. Perttula, and P. Dering

2004 National Register Testing of Siles 4IHE14, 41HE139, and $41 \mathrm{HE} 343$ within Proposed FM 3506 Right of Way, Henderson County, Texas. Report No. 60. Archeological Studies Program, Texas Department of Transportation, Austin.

Corbin, J. E.

2007 Cultural Diversity in the Southern Caddo Region. Journal of Northeasl Texas Archaeology 26:11-23.

Kelley, D. B., T. K. Perttula, D. G. Hunter, B. M. Albert, J. Kelly, B. Nelson, and D. E. Wilson

2006 Interim Report on Archaeological Data Recovery al 4I AN38, Anderson County, Texas. Coastal Environments, Inc., Baton Rouge. 
Kleinschmidt, U. K. W.

1982 Review and Analysis of the A. C. Saunders Site, 41AN19, Anderson County, Texas. Master's thesis, Department of Anthropology, The University of Texas at Austin.

Perttula, T. K. and B. Nelson

2006 Archeological Survey Investigations and Test Excavations at 4 ICE354 at the North and South Lake areas of the H.R.C. Cherokee Tree Farm, L.P. Project, Cherokee County, Texas. Report of Investigations No. 80. Archeological \& Environmental Consultants, LLC, Austin.

Story, D. A. and D. G. Creel

1982 The Cultural Setting. In The Deshazo Site, Nacogdoches County, Texas, Vol. 1: The Site, Its Setting, Investigations, Cultural Features, Artifacts of Non-Native Manufacture, and Subsistence Remains, edited by D. A. Story, pp. 20-34. Texas Antiquities Permit Series No. 7. Texas Antiquities Committee, Austin. 